\title{
Test for the production and assay of the proteolytic activities of halophilic bacteria and archaea isolated from Algerian hypersaline environments
}

\author{
Hania Benmebarek ${ }^{1 *}$, Juan-José Escuder-Rodríguez², María-Isabel González-Siso² and Karima \\ Karroub $^{1}$ \\ ${ }^{1}$ Equipe Métabolites des Extrêmophiles, Laboratoire de Recherche Biotechnologie et Qualité des Aliments \\ (BIOQUAL), Institut de la Nutrition, de l'Alimentation et des Technologies Agro- Alimentaires (INATAA), \\ Université Frères Mentouri Constantine 1 (UFMC1), Route de Ain El Bey, 25000 Constantine, Algérie; \\ ${ }^{2}$ Grupo EXPRELA, Centro de Investigacións Científicas Avanzadas (CICA), Facultade de Ciencias, \\ Universidade da Coruña, 15071 A Coruña, Spain; \\ *Correspondence: benmebarek.hania@umc.edu.dz ; \\ + Presented at the $1^{\text {st }}$ International Electronic Conference on Microbiology, 02-30 November 2020; Available \\ online: https://ecm2020.sciforum.net/
}

Published: 02 November 2020

\begin{abstract}
The present work was carried out on 133 halophilic strains, isolated on MGM medium at 12 and $23 \%(\mathrm{w} / \mathrm{v})$ of salt. A screening of the extracellular proteolytic activities, carried out on the same medium supplemented with casein or gelatin at $1 \%(\mathrm{w} / \mathrm{v})$, allowed us to select 24 bacterial and 21 Archaeal strains presenting a precipitate around the colonies for casein and/or a translucent halo (after addition of Frazier's reagent) for the gelatin. The enzymatic test was done on liquid medium in micro-culture on a $2 \mathrm{~mL}$ Eppendorf tube. The assay of the proteolytic activity using Azocasein as substrate, following 2 protocols the first with PBS and the second with Tris $\mathrm{HCl}$, with positive and negative controls, demonstrated interesting results for 10 strains among the 45 tested including 5 bacteria and 5 archaea. These have undergone morphological, physiological and molecular characterization based on amplification and sequencing of the $16 \mathrm{~S}$ ribosomal RNA gene.
\end{abstract}

Keywords: halophilic bacteria; halophilic archaea; proteolytic activity; hypersaline environments

\section{Introduction}

Microbial life can be found over a wide range of extreme conditions (salinity, $\mathrm{pH}$, temperature, pressure, light intensity, oxygen and nutrient conditions). Hypersaline environments constitute typical examples of environments with extreme conditions due to their high salinity, exposure to high and low temperatures, low oxygen conditions and in some cases, high $\mathrm{pH}$ values. Bacteria and Archaea are the most widely distributed organisms in these environments [1]. These unconventional conditions for life suggest that such microbes use original strategies (specific enzymes) to adapt to physico-chemical constraints that they have to face. Several of these enzymatic activities are nowadays good candidates to be used in biotechnological processes [2]. However, In comparison to other groups of extremophilic microorganisms such as the thermophiles and the alkaliphiles, the halophiles of all three domains have been relatively little exploited [3].

Proteases represent the largest and most important segment in the industrial enzyme market, used in detergents, food processing, and leather industry, as biocatalysts in organic synthesis, and, among many other applications, as therapeutics because their roles are involved in key decisions throughout an organism in several physiological and metabolic processes [4]. Therefore, obtaining 
and preparing pure enzyme which is stable and active under multiple extreme conditions (alkaline $\mathrm{pH}$, high salt concentrations and wide temperature) is scientifically and industrially significant [5].

2. Materiel and methods

\subsection{Samples and strains isolation}

Brine samples used in the present study were collected from two solar saltern on 2016, namely Ezzemoul, Ain M'lila east of Algeria and Betioua, Aarzew west of Algeria. Samples were spread on solid Modified Growth Medium [6], containing 5 g peptone, $1 \mathrm{~g}$ yeast extract with 12.5 and $23 \%$ (w/v) salt concentration, $\mathrm{pH} \quad 7.5$. Prokaryotic isolates were picked after $7-15$ days of incubation at $37^{\circ} \mathrm{C}$, based on colony pigmentation, size, and margin and immediately streak-plated at least 3-4 times on fresh agar plates with the appropriate medium until purity was confirmed [7]. Beside this, 41 strains were recovered from previous work. A total of 133 strains (68 bacteria and 65 Archaea) were preserved on plats at $4^{\circ} \mathrm{C}$.

\section{2. morphology and physiology}

The isolates were submitted to morphology examination using cells from exponentially growing cultures. The colonies' aspect was examined. Cell morphology and Gram was observed. The proteolytic activity of the isolates was screened on solide MGM media $(0.3 \%$ peptone and $0.1 \%$ yeast extract) supplemented with $1 \%(\mathrm{w} / \mathrm{v})$ casein [8], or $1 \%(\mathrm{w} / \mathrm{v})$ gelatin [9], positive results was detected after, 5 days for bacteria and 10 days for archaea, incubating at $37^{\circ} \mathrm{C}$ by the presence of a precipitate around the colonies for casein and/or a translucent halo (after addition of Frazier's reagent) for the gelatin. Growth rates were estimated on MGM liquide medium at different $\mathrm{NaCl}$ concentrations (02,5- 5- 7,5- 10- 12,5- 15- 17,5- 20-22,5- 25 and 27\%). The culture was incubated in aerobic conditions at $37^{\circ} \mathrm{C}$ during $24 \mathrm{~h}$ for bacteria and $4 \_\mathrm{h}$ for archaea. The optical density at $660 \mathrm{~nm}$ was mesured with a Synergy $\mathrm{H} 1$ hybrid multi-mode microplate reader [10].

\subsection{DNA extraction, $16 S$ rRNA gene amplification and strains identification}

The total genomic DNA of 10 proteolytic selected strains, was prepared from colonies resuspended in MilliQ water by heating at $98^{\circ} \mathrm{C} / 10 \mathrm{~min}$ for bacteria and at $72^{\circ} \mathrm{C} / 10 \mathrm{~min}$ for Archaea, followed by centrifugation at $13000 \mathrm{rpm}$ for $5 \mathrm{~min}$ [6]; The tubes were immediately cooled on ice.

Bacterial and archaeal 16S rRNA genes were amplified using primer sets 27F/1492R [11] and $21 F / 1492 R$ [12], respectively. PCR was performed using a $50 \mu \mathrm{L}$ reaction mixture containing the following (per reaction): $5 \mu \mathrm{L}$ of PCR buffer 10x, $4 \mu \mathrm{L}$ of deoxyribonucleotide triphosphate mixture (10mM each), $0.5 \mu \mathrm{L}$ of each primer $(10 \mu \mathrm{M}), 0.25 \mu \mathrm{L}(1.25 \mathrm{U})$ DreamTaq, and $1 \mu \mathrm{L}$ of template DNA. The following PCR conditions were used: $95^{\circ} \mathrm{C}$ for $30 \mathrm{~s}$ followed by 40 cycles of $95^{\circ} \mathrm{C}$ for $30 \mathrm{~s}, 45,2^{\circ} \mathrm{C}$ for $30 \mathrm{~s}$, and $72{ }^{\circ} \mathrm{C}$ for $1 \mathrm{~min}$, and finally an extension step of $8 \mathrm{~min}$ at $72{ }^{\circ} \mathrm{C}$. The amplified DNA supplied with gel-Green was submitted to electrophoresis on $0.7 \%(\mathrm{w} / \mathrm{v})$ agarose gels in (TE) buffer and then visualized under UV light. Identities with described taxa were investigated using the nBLAST tool against the EzBioCloud database of cultured organisms.

\subsection{Enzymatic assay}

The enzymatic assay was carried out using two methods based on azocasein (Sigma, St. Louis, MO, USA) as substrate. Absorbance was performed using a plate reader (using a Synergy H1 Hybrid Multi-Mode Microplate Reader).

Method 1: Cell-free culture supernatants were prepared by centrifugation for $5 \mathrm{~min}$ at 12,000 g. The reaction was performed in $50 \mathrm{mM}$ Phosphate-buffered saline (PBS) solution pH 7.5 with $50 \mu \mathrm{l}$ of azocasein $3 \%(\mathrm{w} / \mathrm{v})$ and with $50 \mu \mathrm{l}$ of culture supernatant for a final volume of $750 \mu \mathrm{l}$. The reaction was incubated at $37^{\circ} \mathrm{C}$ for $1 \mathrm{~h}$ and stopped by adding $125 \mu \mathrm{l}$ of $20 \%(\mathrm{w} / \mathrm{v})$ trichloroacetic acid. Positive control is prepared by using a solution of proteinase $K$, the blank assay was realized using the culture medium. After centrifugation at 15,000 $\mathrm{g}$ for $10 \mathrm{~min}$, the absorbance of the supernatant was measured 
at OD366nm. One unit of protease activity was defined as the amount required to produce enough acid-soluble material from azocasein to yield an absorbance of 0.01 at $366 \mathrm{~nm}$, following $1 \mathrm{~h}$ of incubation $[13,10]$.

Method 2: In this assay, $0.5 \mathrm{~mL}$ of reaction mixture consisting of $0.25 \mathrm{~mL}$ of crude enzyme (cellfree supernatant) and $0.25 \mathrm{~mL}$ of $0.8 \%(\mathrm{w} / \mathrm{v})$ azocasein in $0.1 \mathrm{M}$ Tris- $\mathrm{HCl}$ buffer $(\mathrm{pH} 8.0)$ containing $\mathrm{NaCl}$ at $12.5 \%(\mathrm{w} / \mathrm{v})$ for bacteria and $23 \%(\mathrm{w} / \mathrm{v})$ for archaea. The reaction mixture was incubated at $37^{\circ} \mathrm{C}$ for $2 \mathrm{~h}$ with mild shaking. The reaction was terminated by adding $0.5 \mathrm{~mL}$ of $10 \%(\mathrm{w} / \mathrm{v})$ trichloroacetic acid and the mixture was allowed to stand at room temperature for $30 \mathrm{~min}$. The precipitate was removed by centrifugation at 10,000 rpm for $10 \mathrm{~min}$. Subsequently, a volume of 300 $\mathrm{mL}$ of the initial supernatant fluid was transferred into a microcentrifuge tube and then mixed with $350 \mathrm{~mL}$ of $1.0 \mathrm{~N} \mathrm{NaOH}$. The absorbance was measured at $440 \mathrm{~nm}$. One unit (U) of halophilic protease activity was defined as the amount of enzyme activity that produces a change in absorbance of 0.01 at $440 \mathrm{~nm}$ in $2 \mathrm{~h}$ at $37^{\circ} \mathrm{C}$ under the standard assay conditions. The halophilic protease activity was calculated according to the following equation:

$$
\text { Halophilic protease activity }(\mathrm{U} / \mu \mathrm{l})=\frac{(A-B) * V t}{V e * 0.01}
$$

Where A and B are the optical densities of the crude enzyme and the control, respectively, $V t$ is the total reaction volume and $V e$ is the volume of crude enzyme [14, 15].

\section{Results}

\subsection{Morphology and physiology}

Morphological aspect of cells for 45 proteolytic strains showed that most of archaea are Gram positive with cocci dominant, and for bacteria we find the two types of Gram with rod- shaped are the dominant as shown in table 1.

Table 1. Morpholigical aspect of proteolytic Bacteria and Archaea isolates.

\begin{tabular}{cccccccc}
\hline & \multicolumn{2}{c}{ Gram } & \multicolumn{2}{c}{ Cell form } & \multicolumn{2}{c}{ Protease } \\
\hline & Positive & Negative & Cocci & Rod & Coccobacilli & Casein & Gelatin \\
\hline Bacteria & 8 & 16 & 3 & 16 & 5 & 16 & 23 \\
\hline Archaea & 1 & 17 & 12 & 3 & 3 & 0 & 21 \\
\hline
\end{tabular}

The growth rates of selected strains were estimated as described before. Results in figure 1, demonstrate that the bacteria strain 4 have a large salinity growth interval $(2.5-17,5 \%, \mathrm{w} / \mathrm{v})$, which mean that it is a moderately halophilic bacteria, in addition, the archaea strain $\mathrm{N}$ have a growth salt interval from 15 to $27 \%(\mathrm{w} / \mathrm{v})$, suggesting that it is an extreme halophile [16].

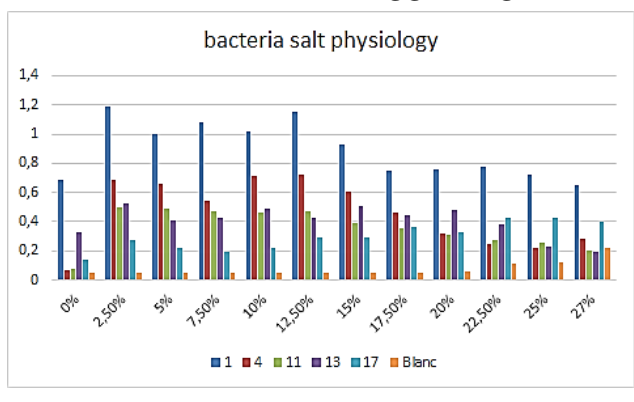

(a)

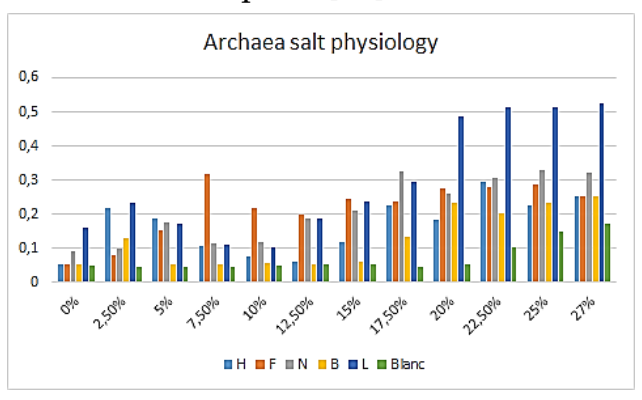

(b)

Figure 1. salt optima for selected bacteria and archaea strains: (a) growth rates OD600nm of bacteria on different salt concentration liquid MGM medium; (b) growth rates OD600nm of archaea on different salt concentration liquid MGM medium.

\subsection{Identification by $16 S \mathrm{rRNA}$ gene analysis}


The $16 \mathrm{~S}$ rRNA gene analysis related their grouping in seven genera; Virgibacillus, Idiomarina, Halobacillus, for bacteria; Halorubrum, Halobacterium, Halogeometricum, and Natrinema for archaea. Bacteria Gram negative isolates of Idiomarina genus belonged to Gammaproteobacteria Class, Idiomarinacaea family and Gram positive of Virgibacillus and Halobacillus belonged to Bacilli Class, Bacillaceae family [16, 17]. Archaea genera are all belonged to_Halobacteria Class, Halorubrum : Halorubraceae family; Natrinema: Natrialbaceae family; Halobacterium: Halobacteriaceae family; Halogeometricum: Haloferacaceae. With high salt tolerance and generally pigment production [16].

\subsection{Enzymatic assay}

The enzymatic assay was first performed for the 45 proteolytic selected strains with azocasein using PBS buffer [13, 10], after production on casein and gelatin media. Results presented on figures 2 and 3 allowed us to select 5 bacteria and 5 archaea that shown interesting enzymatic activity: 1, 4, 11,13 and 17 for bacteria ; B, F, H, L and N for archaea.

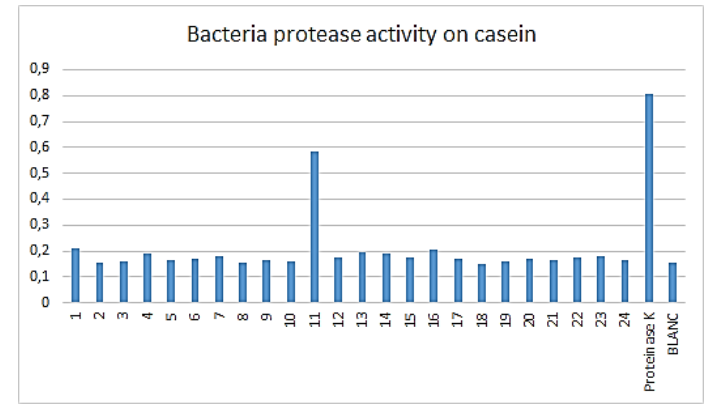

(a)

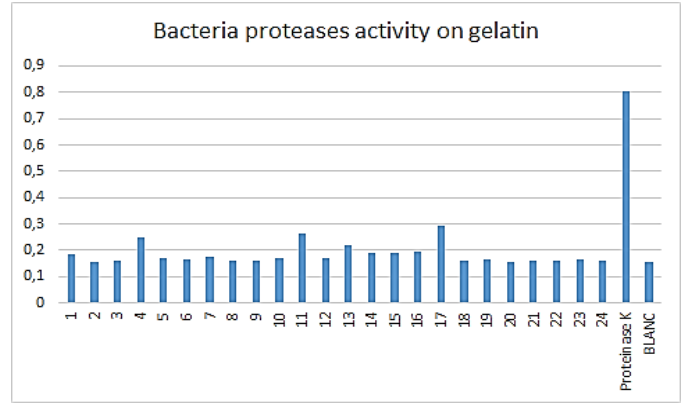

(b)

Figure 2. Bacterial proteasic activity assay tested on azocasein at 366nm: (a) OD366nm for bacterial activities on casein ; (b) OD366nm for bacterial activities on gelatin.

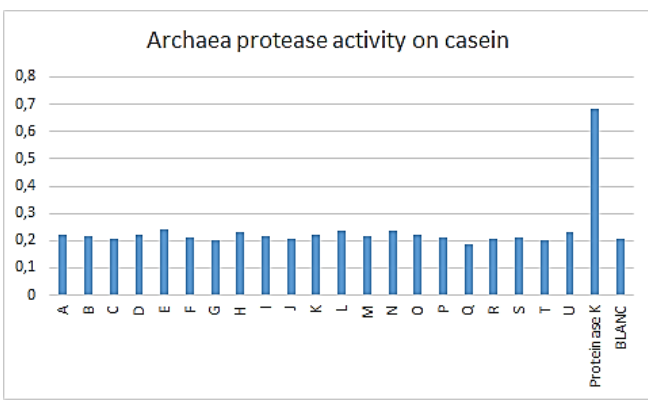

(a)

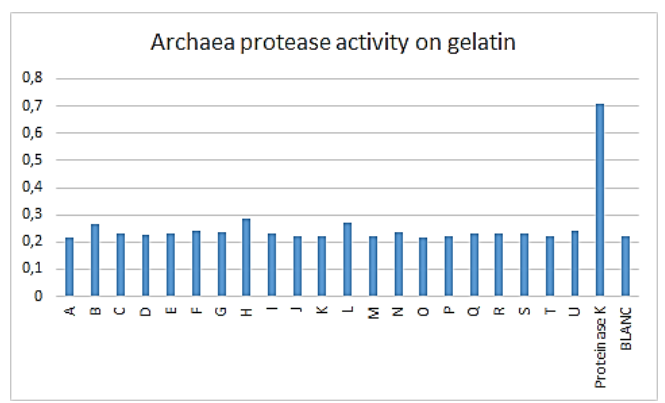

(b)

Figure 3. Archaeal proteasic activity assay tested on azocasein at 366nm: (a) OD366nm for archaeal activities on casein; (b) OD366nm for archaeal activities on casein.

The enzymatic assay was confirmed for archaeal strains using a second method based on azocasein also but in Tris- $\mathrm{HCl}$ buffer and including $\mathrm{NaCl} 23 \%(\mathrm{w} / \mathrm{v})$ as described upper [15]. This time, results presented on figure 4 confirm a good proteolytic activity for only four strains: $L, M, N$ and U.

For further tests, we combine the two methods results and select only four strains: 4 and 11 for bacteria, $\mathrm{H}$ and $\mathrm{N}$ for archaea. 


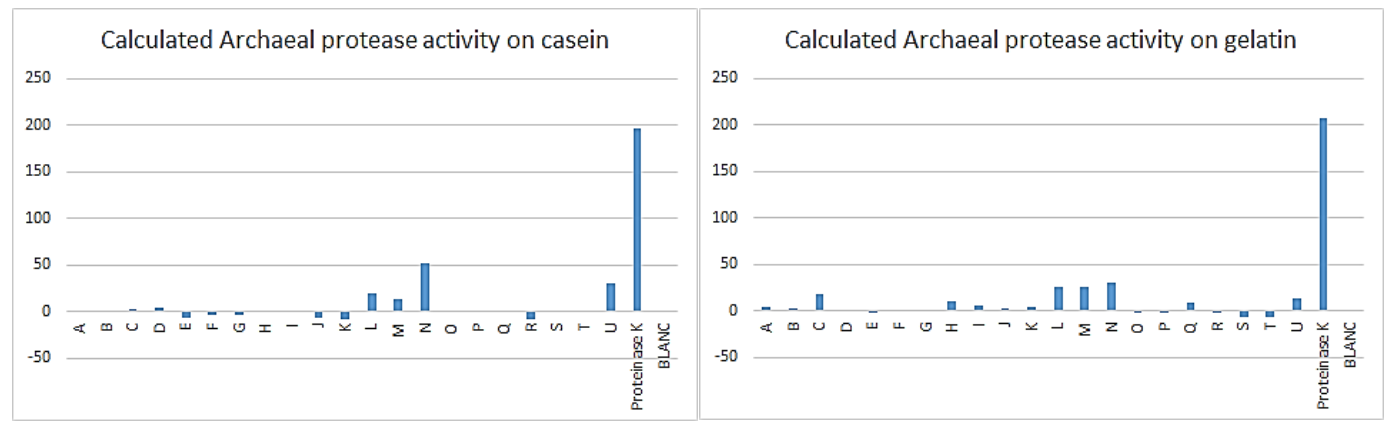

(a)

(b)

Figure 4. Archaeal proteasic activity assay tested on azocasein at 440nm: (a) OD440nm for archaeal activities on casein ; (b) OD440nm for archaeal activities on gelatine.

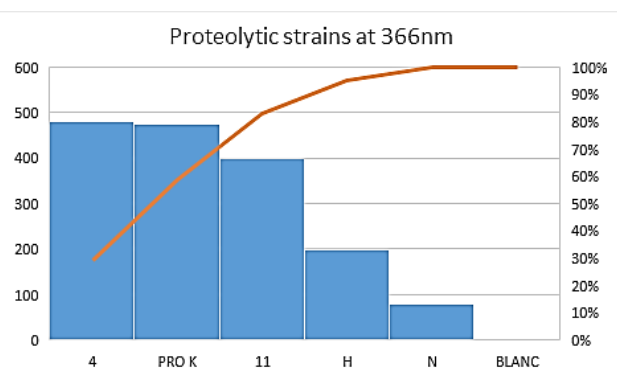

(a)

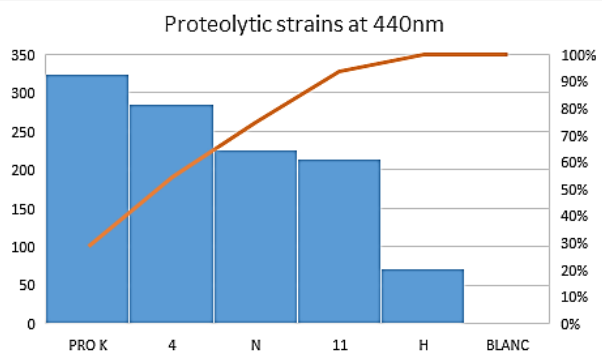

(b)

Figure 5. Determination of proteolytic activity for selected strains. (a) at OD366nm; (b) at OD440nm.

The enzymatic activity (figure 5) for Selected proteolytic bacteria and archaea isolates, estimated with the two methods showed a very good activity, in comparison with the positive control, especially with bacteria strain 4 (Idiomarina sp.) that conserve it's proteolytic properties with the two methods, which means that in absent of $\mathrm{NaCl}(0 \%, \mathrm{w} / \mathrm{v})$ or presence $(12.5 \%, \mathrm{w} / \mathrm{v})$ the proteolysis is well done.

For archaea, the strain $\mathrm{N}$ (Natrinema sp.) showed a good proteolytic activity with the second method in presence of $\mathrm{NaCl}(23 \%, \mathrm{w} / \mathrm{v})$, which is reported by other studies [18, 19] however, the activity is completely lost in the first one probably because of salt missing.

If we combine this results with those of salt physiology, demonstrated in figure 1, we can easily see that Idiomarina $s p$. conserve it's proteolytic activity due to the large salinity growth interval (2.5 $17.5 \%, \mathrm{w} / \mathrm{v})$, at the same time, the archaea Nitronema $s p$. require a high salt concentration, which explain the proteolytic activity lost in the first enzymatic assay.

\section{Conclusion}

The proteolytic activity production from archaeal and bacterial microorganisms isolated from Algerian sites was investigated in this study. 45 Halophilic isolates were able to produce protease. Extremely halophilic archaeal isolates were affiliated to Natrinema, Halorubrum, Halobacterium, halogeomatricum and bacterial isolates to Virgibacillus, Idiomarina, and Halobacillus genera, of which several strains could produce hydrolytic enzymes. This study that the genera Idiomarina and Natrinema showed the most important proteolytic activity (Figure 5).

According to the results, it is suggested that Natrinema and Idiomarina genera are excellent candidates for production the proteolytic enzymes . Proteolytic activity produced by Natrinema under high salinity condition could made this strain an interesting candidate for future investigation. Those extremely halophilic isolates were selected for further studies for their great biotechnological applications with respect to their capacity to produce different hydrolases. It would be more 
constructive if these enzymes are purified from the isolates and then characterized, which is the next step in the current work.

Acknowledgments: We wish to acknowledge the following organizations for providing financial support for this study: the Algerian Ministry of Higher Education and Scientific Research, and The laboratory of the group EXPRELA (Universidade da Coruña, Spain).

Conflicts of Interest: The authors declare no conflict of interest.

\section{References}

1. Moreno, M. de L., Pérez, D., García, M. T., \& Mellado, E. (2013). Halophilic bacteria as a source of novel hydrolytic enzymes. Life, 3(1), 38-51. https://doi.org/10.3390/life3010038

2. De, L., Grégoire, P., \& Bonin, P. C. (2009). Les micro-organismes de l'extrême. January.

3. Ma, Y., Galinski, E. A., Grant, W. D., Oren, A., \& Ventosa, A. (2010). Halophiles 2010: Life in saline environments. Applied and Environmental Microbiology, 76(21), 6971-6981. https://doi.org/10.1128/AEM.01868-10

4. Côlho, D. F., Saturnino, T. P., Fernandes, F. F., Mazzola, P. G., Silveira, E., \& Tambourgi, E. B. (2016). Azocasein Substrate for Determination of Proteolytic Activity: Reexamining a Traditional Method Using Bromelain Samples. BioMed Research International, 2016. https://doi.org/10.1155/2016/8409183

5. Ghafoori, H., Askari, M., \& Sarikhan, S. (2016). Purification and characterization of an extracellular haloalkaline serine protease from the moderately halophilic bacterium, Bacillus iranensis (X5B). Extremophiles, 20(2), 115-123. https://doi.org/10.1007/s00792-015-0804-8

6. Nuttall, S., Bath, C., Pfeiffer, M., Santos, F., Eichler, J., \& Mcalpine, T. (2008). The Halohandbook. Media, March, 1-144. http://scholar.google.com/scholar?hl=en\&btnG=Search\&q=intitle:The+Halohandbook\#0

7. Dammak, D. F., Smaoui, S. M., Ghanmi, F., Boujelben, I., \& Maalej, S. (2016). Characterization of haloalkaline and thermostable protease from Halorubrum ezzemoulense strain ETR14 isolated from Sfax solar saltern in Tunisia. Journal of Basic Microbiology, 56(4), 337-346. https://doi.org/10.1002/jobm.201500475

8. Cojoc, R., Academy, R., Popescu, G. T., Academy, R., Enache, M., \& Academy, R. (2009). Extracellular hydrolytic enzymes of halophilic bacteria isolated from a subterranean rock salt crystal Extracellular hydrolytic enzymes of halophilic bacteria isolated from a subterranean rock salt crystal Introduction During several periods in the Earth's history, massive sedimentation of halite from. September.

9. Gutiérrez, C., \& González, C. (1972). Method for simultaneous detection of proteinase and esterase activities in extremely halophilic bacteria. Applied Microbiology, 24(3), 516-517. https://doi.org/10.1128/aem.24.3.516-517.1972

10. Gomri MA., Rico-Díaz A., Escuder-Rodríguez J.J., Khaldi T.M., González-Siso M.I. \& Kharroub K.(2018). Production and Characterization of an Extracellular Acid Protease from Thermophilic Brevibacillus sp. OA30 Isolated from an Algerian Hot Spring. https://doi.org/10.3390/microorganisms6020031

11. Siroosi, M., Amoozegar, M. A., Khajeh, K., Fazeli, M., \& Habibi Rezaei, M. (2014). Purification and characterization of a novel extracellular halophilic and organic solvent-tolerant amylopullulanase from the haloarchaeon, Halorubrum sp. strain Ha25. Extremophiles, 18(1), 25-33. https://doi.org/10.1007/s00792-0130589-6

12. Galkiewicz, J. P., \& Kellogg, C. A. (2008). Cross-kingdom amplification using Bacteria-specific primers: Complications for studies of coral microbial ecology. Applied and Environmental Microbiology, 74(24), 78287831. https://doi.org/10.1128/AEM.01303-08

13. Guendouze, A., Plener, L., Bzdrenga, J., Jacquet, P., Rémy, B., Elias, M., Lavigne, J. P., Daudé, D., \& Chabrière, E. (2017). Effect of quorum quenching lactonase in clinical isolates of pseudomonas aeruginosa 
and comparison with quorum sensing inhibitors. Frontiers in Microbiology, 8(FEB), 1-10. https://doi.org/10.3389/fmicb.2017.00227

14. Brock, F. M., Forsberg, C. W., \& Buchanan-Smith, J. G. (1982). Proteolytic activity of rumen microorganisms and effects of proteinase inhibitors. Applied and Environmental Microbiology, 44(3), 561-569. https://doi.org/10.1128/aem.44.3.561-569.1982

15. Chuprom, J., Bovornreungroj, P., Ahmad, M., Kantachote, D., \& Dueramae, S. (2016). Approach toward enhancement of halophilic protease production by Halobacterium sp. strain LBU50301 using statistical design response surface methodology. Biotechnology Reports, 10, 17-28. https://doi.org/10.1016/j.btre.2016.02.004

16. Satyanarayana, T., Prakash, A., \& Johri, B. N. (2012). Microorganisms in environmental management: Microbes and environment. In Microorganisms in Environmental Management: Microbes and Environment (Vol. 9789400722293, Issue January). https://doi.org/10.1007/978-94-007-2229-3

17. Sánchez-porro, C. (2011). Extremophiles Handbook. In Extremophiles Handbook (Issue June 2015). https://doi.org/10.1007/978-4-431-53898-1

18. Cojoc R, Merciu S, Popescu G et al (2009) Extracellular hydrolytic enzymes of halophilic bacteria isolated from a subterranean rock salt crystal. Rom Biotechnol Lett 14:4658-4664

19. Karray, F., Ben Abdallah, M., Kallel, N., Hamza, M., Fakhfakh, M., \& Sayadi, S. (2018). Extracellular hydrolytic enzymes produced by halophilic bacteria and archaea isolated from hypersaline lake. Molecular Biology Reports, 45(5), 1297-1309. https://doi.org/10.1007/s11033-018-4286-5

Publisher's Note: MDPI stays neutral with regard to jurisdictional claims in published maps and institutional affiliations.

(C) 2020 by the authors. Submitted for possible open access publication under the terms and conditions of the Creative Commons Attribution (CC BY) license (http://creativecommons.org/licenses/by/4.0/). 